NEWS

\title{
Diabetes drugs offered fresh start
}

\section{As FDA advisers vote for restrictions on Avandia, researchers reveal a way to make such drugs safer.}

When the erstwhile blockbuster diabetes drug Avandia stood trial before the US Food and Drug Administration (FDA) last week, its sharpest critics pulled no punches. Among them was Steven Nissen, the cardiologist at Ohio's Cleveland Clinic who first exposed Avandia's heartattack risk. Shortly before yielding the podium, he unleashed a parting salvo against not just Avandia, but also the drug's family.

Since Avandia (rosiglitazone) hit the market, he said, developers have wasted their time on at least 50 other drugs that act by a similar mechanism. All of them failed, Nissen said, some because they posed similar risks to the heart.

A paper in this week's issue of Nature (page 451) details a way in which drugs of this class might avoid such dismal fates. The results could help drug makers to tailor compounds that reduce blood sugar without harmful cardiovascular side effects. Some observers doubt that pharmaceutical companies will try, given the protracted battle over Avandia and the failure of its relatives. "At present, this class of drugs is tainted," says Steven Kliewer, a molecular biologist at the University of Texas Southwestern Medical Center at Dallas, who helped to develop rosiglitazone. "The big pharma companies have basically given up on them."

Nevertheless, there is plenty of incentive for industry to persist as the obesity epidemic spawns a growing pool of patients with type 2 diabetes. The market for diabetes treatments is expected to grow from US $\$ 20.2$ billion in 2008 to $\$ 37.9$ billion in 2018 , according to the market-research firm Datamonitor.

Swelling demand such as this helped to make
Avandia a blockbuster, achieving sales of $£ 1.66$ billion (some US $\$ 3$ billion) for manufacturer GlaxoSmithKline in 2006. But after studies found that the drug boosted heart-attack risk, the FDA slapped it with a warning in 2007. Finally, at the FDA meeting on 13-14 July in Gaithersburg, Maryland, the majority of a 33-strong advisory panel recommended restricting the drug's distribution. Twelve wanted Avandia to be pulled from the market altogether. The FDA is not required to follow the advice of such panels, but often does.

Throughout the affair, the reasons for the drug family's unwanted side effects have been unclear. In 2000, a related drug, Rezulin (troglitazone), was yanked from the market for causing liver failure (see 'Meet the 'glitazones': Avandia's family history'). Although Actos (pioglitazone)

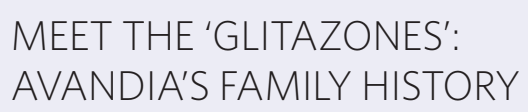

气 Glaxo researchers report $\equiv$ that 'glitazone' drugs act via a protein called PPAR- $\gamma$.
त̄ FDA approves Avandia

$\sum_{i}^{\infty}$ (rosiglitazone).

FDA approves Actos

三 (pioglitazone).

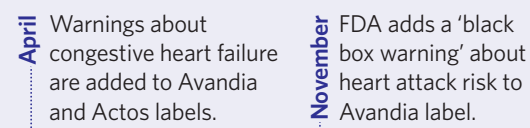
and Actos labels.

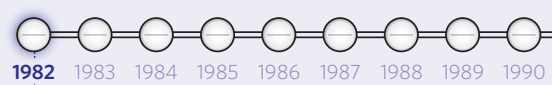

A compound called ciglitazone is shown to

o lower blood sugar in mice, but is never used ○ in humans.

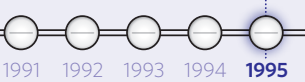

产 FDA approves Rezulin (troglitazone) to treat

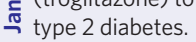
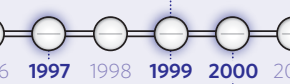

Sezulin is removed
U from the market
$\sum^{\frac{\pi}{J}}$ owing to liver toxicity.

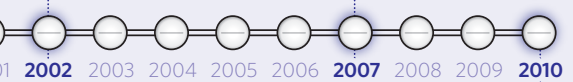

FDA advisory committee recommends $\geq$ restricting Avandia sales or removing it ב from the market.

\section{UK government warned over 'catastrophic' cuts}

British science funders have been ordered by the government to draw up detailed plans for coping with inevitable budget cuts later this year. While publicly lobbying to avoid major damage, the agencies are privately preparing for financial futures that range from merely gloomy to 'catastrophic'.

The true state of British science funding will not be revealed until after 20 October, when the government announces how it plans to cut roughly $25 \%$ from the budget of each of its departments.

But this week saw the seven research councils - which between them hand out $€ 3$ billion (US $\$ 4.6$ billion) of government money each year in grants - make a second round of requested PowerPoint presentations to the Department for Business, Innovation and Skills (BIS), which determines their budgets. They looked at how they would tackle three scenarios: a budget freeze, or cuts of $10 \%$ and $20 \%$ over four years.

Adding to the pain, inflation would cut an extra $10 \%$ in real terms from the budgets over the four years (see graph). And the councils worry that a cut in public cash will lead to a loss of matched funding from private companies, or in money coming into research centres from contract research.

Britain's national academy of science, the Royal Society, told BIS in a report released on 16 July that a $20 \%$ cut would be "irreversibly catastrophic for the future of UK science and economic growth". Under the heading "Game over", it predicted that star researchers would leave Britain, that higher-education funding councils would be unlikely to maintain support to universities for PhD training, and that research councils would slash the number of PhD grants, "destroying an entire generation of home-grown scientists". Alternatively, a 10\% cash cut would be "damaging", the society said, and a flat-cash settlement would be "painful but manageable".

Some research councils say that in a budget freeze they would trim cash across the board from existing strategies. "With flat cash you can just about squeeze everything over time," says David Bloomer, director of finance and operations at the Natural Environment Research Council (NERC).

More severe cuts would force the councils to make tough choices, favouring some areas at the expense of others. "Some research areas will lose out. There's not much I can say to soften the blow," the Medical Research Council's chief executive, Leszek Borysiewicz, told scientists funded by his agency in 
remains on the market and does not seem to pose a heart-attack risk, both it and Avandia roughly double the risk of heart failure.

Each of these glitazones activates a receptor in cell nuclei called PPAR- $\gamma$, boosting a pathway that ups the body's sensitivity to insulin and lowers blood sugar levels. But new work by molecular biologist Bruce Spiegelman at Harvard Medical School in Boston, Massachusetts, and his colleagues suggests that Avandia's effects on blood sugar may not depend on PPAR- $\gamma$ activation after all.

The team found that, in obese mice, a phosphate is attached to a specific site on PPAR- $\gamma$, altering the receptor's function and reducing insulin sensitivity. Furthermore, Avandia and a similar compound called MRL24 not only activated PPAR- $\gamma$, but also often blocked the addition of the phosphate. And MRL24, which only weakly activates the receptor, was just as effective at lowering blood sugar in mice as Avandia, a potent PPAR- $\gamma$ activator.

The results, says Spiegelman, suggest that pharmaceutical companies focused on the wrong activity when screening for PPAR- $\gamma$ altering drugs. Drugs that are more specific and only block the addition of the phosphate to PPAR- $\gamma$ may work just as well without the same risk of side effects, he says.

The door is open for companies to redo their screens. Robert Henry, an endocrinologist at the University of California, San Diego, believes that drug makers will be interested despite the glitazones' rocky history. "Obesity is such a horrific problem and its consequences

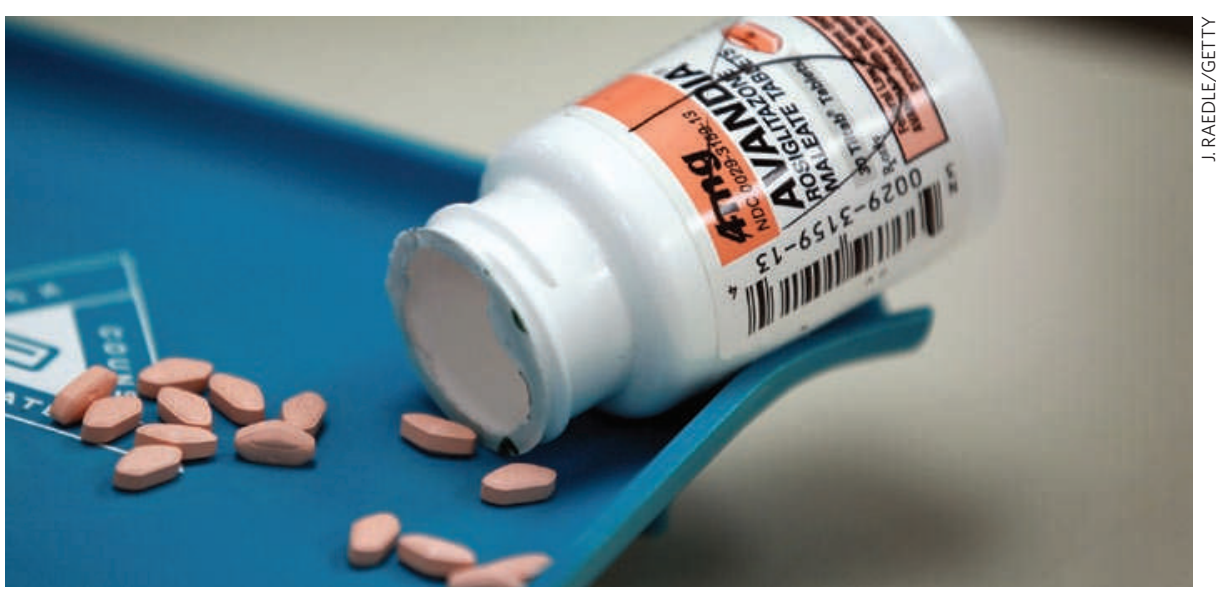

A study suggests a way in which the dangerous side effects of drugs such as Avandia might be avoided.

are so widespread, this work is crucial."

But endocrinologist Clay Semenkovich of Washington University in St. Louis, Missouri, says that Spiegelman's work, although "interesting and provocative", is still preliminary. In particular, he notes, the human experiments didn't include a control group of people who didn't receive a drug. Instead, control samples were taken from each patient before they embarked on a six-month treatment schedule. "A lot can change about a person in six months," Semenkovich says.

In any case, drugs that work by different mechanisms are already on the market. One class, the gliptins, inhibits an enzyme that breaks down an insulin-releasing hormone — thereby increasing the insulin available to diabetics. And another, inhibitors of the protein SGLT2, currently in late-stage clinical trials, keep blood sugar levels down by blocking the uptake of glucose by the kidneys. As a result, excess sugar is excreted in the urine.

David Nathan, director of the Diabetes Center at Massachusetts General Hospital in Boston, says Avandia should never have been a blockbuster because even its predecessors drugs such as insulin and metformin - control blood sugar better. "I was never convinced that this was a great class of drugs to start with," he says. "There was nothing magical about it. It was all a triumph of advertising."

Heidi Ledford

See Editorial, page 413, and News \& Views, page 443.
FROM BAD TO WORSE Even an optimistic flat-funding scenario means real-term cuts to UK science.

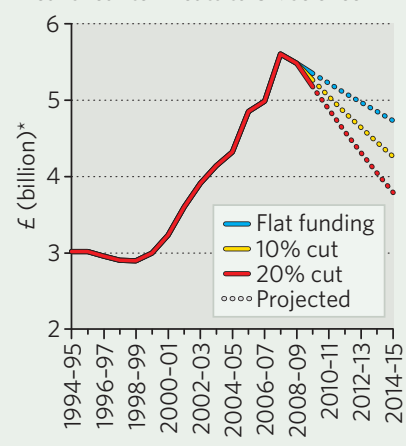

*Government science and engineering base funding. adjusted to $2006-07$ value; assumes $2.5 \%$ inflation.

the 9 July issue of the MRC Network newsletter.

David Delpy, chief executive of the Engineering and Physical Sciences Research Council (EPSRC), says that in the case of severe cuts, his council would support work in which Britain has the potential to benefit economically. The EPSRC would use existing international reviews to decide what to cut and what to keep. But Delpy predicts that the council's contribution to seven previously agreed cross-council 'Grand Challenge' programmes (in such areas as nanotechnology, ageing and energy) would be a priority - a sentiment echoed by other research councils.

Making cuts will be particularly difficult for agencies whose funds are tied up in supporting infrastructure or international subscriptions. According to the Royal Society, the Biotechnology and Biological Sciences Research Council spends some $14 \%$ of its funding on these inflexible areas - the rest goes on grants for projects or individuals - but NERC spends $57 \%$ on facilities such as environment-monitoring aircraft and ocean-going research ships. These large units are hard to cut back. "You can't have $10 \%$ less of a ship," notes Bloomer.

Privately, the research councils are comparing notes - partly to ensure that they don't pull in different directions - and are presenting the different scenarios to universities. "My sense is that the EPSRC has been frank and open in discussing the potential problems, at least with their biggest partner universities," says Richard Jones, pro-vice-chancellor for research and innovation at the University of Sheffield, UK. But the research councils and learned societies will not talk publicly about specific areas or institutions that might face the axe, for fear of encouraging those cuts to take place.

The Royal Academy of

Engineering, however, broke this mutually agreed silence on 8 July by publishing its submission to BIS, in which it argued that Britain was spending too much on particle physics, rather than on subjects with clearer economic benefits - such as those under its own purview. The physicists' learned society, the Institute of Physics, responded swiftly with its own letter to $\mathrm{BIS}$ reiterating the importance of particle physics, but it would not publicly release the document.

"At this stage, we should all be arguing for the size of the cake, not how it should be carved up," says the Royal Society's director of policy, James Wilsdon.

Richard Van Noorden 